\title{
Safety and efficacy of nateglinide/metformin combination therapy in the treatment of type 2 diabetes
}

\author{
Marc K Israel' \\ Eva Istvan² \\ Michelle A Baron ${ }^{1,3}$ \\ 'Novartis Pharmaceuticals \\ Corporation, East Hanover, New \\ Jersey, USA; ${ }^{2}$ Novartis AG, Basel, \\ Switzerland; ${ }^{3}$ Sanofi-Aventis, \\ Bridgewater, New Jersey, USA
}

\begin{abstract}
The increasing prevalence of type 2 diabetes provides impetus for both development of new drugs to improve glycemic control and for reconsideration of treatment strategies with existing agents. Combination therapy with complementary drug classes that act on different aspects of glycemic control has been a particularly effective strategy. This work reviews the published literature reporting efficacy and safety/tolerability of nateglinide, a rapid-onset insulinotropic agent with a predominant effect to reduce postprandial glucose, when combined with metformin, a first-line agent that suppresses hepatic glucose production and thereby reduces fasting plasma glucose. The nateglinide/metformin combination has consistently been found to be both efficacious and well tolerated, whether given as initial combination therapy in drugnaïve patients or when added to metformin monotherapy. Maximum efficacy ( $\Delta$ glycosylated hemoglobin $\left[\mathrm{HbA}_{1 \mathrm{c}}\right]=-1.4 \%$ to $-1.9 \%$, sustained for up to 2 years of treatment) was seen in studies of drug-naïve patients in whom pharmacotherapy was initiated with the combination of nateglinide and metformin, and modest reductions in $\mathrm{HbA}_{1 \mathrm{c}}(\Delta=-0.5 \%$ to $-1.2 \%$, sustained for up to 24 weeks) were found when nateglinide was added to ongoing metformin monotherapy. Conclusion: the combination of nateglinide and metformin provides a sustained degree of glycemic control not achievable with either agent given as monotherapy.

Keywords: metformin, nateglinide, combination therapy, type 2 diabetes, postprandial hyperglycemia
\end{abstract}

\section{Introduction}

The total prevalence of diabetes in the United States (both diagnosed and undiagnosed) is estimated to be 7\%, representing 20.7 million people (Centers for Disease Control and Prevention 2005). Population models based on data from the National Health and Nutrition Examination Survey (NHANES) project a diabetes burden of $14.5 \%$ of the total population (37.7 million people) by 2031 (Mainous et al 2007). Globally, the prevalence of diagnosed diabetes was estimated to be $2.8 \%$ in 2000 (171 million people) and is projected to rise to $4.4 \%$ by 2030 (366 million people) (Wild et al 2004). Moreover, it should be recognized that for every 2 people with known diabetes there is another with undiagnosed diabetes. This epidemic of diabetes is driven by Westernization in developing countries, by the increasing prevalence of obesity, and by the aging of the global population (Wild et al 2004). Models based on NHANES and census data project that, at age 18, the lifetime risk of developing diabetes exceeds $50 \%$ in obese individuals (body mass index [BMI] $\geq 30$ but $<35 \mathrm{~kg} / \mathrm{m}^{2}$ ) (Narayan et al 2007).

The health-care burden that would be imposed by treating the medical consequences of diabetes in such large numbers of patients is enormous and has given impetus 
for the development of new drugs to treat type 2 diabetes (T2DM, accounting for $90 \%-95 \%$ of all diabetes) more effectively and to a reconsideration of treatment strategies with existing agents. Diabetes is difficult to control with a single oral agent. Many patients fail to achieve adequate glycemic control (glycosylated hemoglobin $\left[\mathrm{HbA}_{1 \mathrm{c}}\right]<7.0 \%$ ) with monotherapy (particularly those with high baseline values) and even of those initially achieving good control, less than half will maintain this target level for 2 years (Cook et al 2007). Such observations have stimulated the development of combination therapies that match drugs with complementary mechanisms of action in the hope of obtaining better and longer-lasting glycemic control.

\section{Rationale for combining metformin and nateglinide}

Type 2 diabetes is a chronic, progressive disorder that results from inadequate $\beta$-cell compensation for, or adaptation to, insulin resistance (Kahn 2003). Thus, both insulin resistance and $\beta$-cell dysfunction precede the development of overt diabetes (Weyer et al 1999). Furthermore, with increasing severity of glycemic dysregulation, the progressive decline in $\beta$-cell function is accompanied by an increasingly important contribution of excessive hepatic glucose production (HGP) (DeFronzo et al 1989). Not surprisingly, therefore, no single oral antidiabetic drug (OAD) has been found to provide adequate, prolonged glycemic control as diabetes progresses, and there is a strong scientific rationale for combining OADs with complementary modes of action, ie, that target different pathogenetic factors.

Metformin, a biguanide, acts by decreasing HGP and increasing glucose clearance (Natali et al 2006); it is the recommended first-line pharmacologic treatment for T2DM worldwide (Nathan et al 2006). Metformin primarily reduces fasting plasma glucose (FPG); it has no direct effect on $\beta$-cell function, and it is ineffective in the absence of insulin (Bailey et al 1996). In patients with moderate- to poorly-controlled T2DM, metformin monotherapy was found to decrease FPG by $60 \mathrm{mg} / \mathrm{dL}$ to $70 \mathrm{mg} / \mathrm{dL}$ and $\mathrm{HbA}_{1 \mathrm{c}}$ by $1.5 \%$ to $2 \%$ (DeFronzo 1999), but only about $25 \%$ of patients achieved the American Diabetes Association (ADA)-recommended goal of $\mathrm{HbA}_{1 \mathrm{c}}<7.0 \%$ (DeFronzo et al 1995). Metformin has a very low potential to induce hypoglycemia and, as with all OADs, the magnitude of reduction in $\mathrm{HbA}_{1 \mathrm{c}}$ is proportional to the baseline value.

Nateglinide is one of a newer class of OADs, the "glinides," which are rapid-onset, insulinotropic agents unrelated to the sulfonylureas. These agents are taken before meals (ac) and rapidly increase insulin secretion, essentially restoring (or replacing) the early insulin response, which is lost in patients with T2DM. These agents predominantly decrease postprandial glucose (PPG), which is an independent predictor of negative cardiovascular outcomes (Qiao et al 2002), thought to be mediated by oxidative stress (Ceriello 2000). Nateglinide is unique among glinides in that its pharmacodynamics closely match its pharmacokinetics, so it has both a rapid onset and short duration of action (McLeod 2004). Other glinides, such as repaglinide, have pharmacokinetics similar to those of nateglinide, but because of slow receptor dissociation, their insulinotropic actions are prolonged well beyond clearance of the drugs (Pratley et al 2001). This results in essentially identical reductions in PPG with the 2 agents, somewhat larger decreases in FPG and $\mathrm{HbA}_{1 \mathrm{c}}$ with repaglinide than with nateglinide, but with substantially increased frequency of hypoglycemia with repaglinide than with nateglinide (Rosenstock et al 2004). In patients nearing glycemic targets, hypoglycemia becomes an increasingly important concern.

When given as monotherapy to patients with moderate- to poorly-controlled T2DM, nateglinide (120 mg ac) monotherapy reduced $\mathrm{HbA}_{1 \mathrm{c}}$ by $1.0 \%$ and FPG by $18 \mathrm{mg} / \mathrm{dL}$, with no hypoglycemia (Rosenstock et al 2004). Because of their complementary modes of action, and their very low potential to elicit hypoglycemia, the combination of metformin and nateglinide would be predicted to be both safe and effective for the treatment of T2DM.

The purpose of this paper is to review all available information about the efficacy and safety of nateglinide in combination with metformin, whether used as initial combination therapy or with nateglinide added to ongoing metformin treatment.

\section{Methods}

To identify all published literature on the efficacy and safety/ tolerability of nateglinide when combined with metformin in patients with T2DM, a search was performed of Medline, EMBASE, Biosis Previews, Current Contents, International Pharmaceutical Abstracts, and Cochrane Reviews, for publications appearing from 1998 to 2008. The search was limited to English language journals and required that both nateglinide (or synonyms) and metformin (or synonyms) appear as keywords in titles or in abstracts.

Eight review articles and 25 original publications were identified. Of the 25 original publications, 5 were abstracts (4 of which described studies that were subsequently reported in full papers, and 1 of which provided insufficient 
information to understand the study design or efficacy results), 4 dealt with health economics, 3 were nonclinical, 1 described a clinical study of $<12$ weeks' duration, and 1 reported on safety but included no efficacy data. Thus, only 11 publications reported original findings relating to the efficacy and tolerability of $\geq 12$-week treatment with the nateglinide/metformin combination. The 8 review articles were obtained, and examination of their reference lists revealed no additional original publications describing the efficacy and safety of nateglinide in combination with metformin.

\section{Clinical trials of metformin/nateglinide combination therapy for T2DM}

Table 1 summarizes the study design and efficacy results from the 11 original publications. The publications include data from more than 12,500 patients who received nateglinide in combination with metformin for $\geq 16$ weeks, and the mean baseline $\mathrm{HbA}_{1 \mathrm{c}}$ levels ranged from $\sim 7.6 \%$ to $8.4 \%$.

Five of the 11 publications provide results from doubleblind, randomized, controlled clinical trials (RCTs), 2 describe analyzes of subpopulations included in blinded RCTs, 1 was a 6-month extension of a blinded RCT, and 3 were open-label studies, 1 of which was an observational study of $>11,000$ patients treated under general practice conditions.

\section{Randomized, double-blind trials}

Five double-blind, RCTs have assessed the efficacy and safety of the combination of metformin and nateglinide for the treatment of T2DM. Horton et al (2000) performed a 24-week, parallel-group study in patients randomized to receive nateglinide (120 $\mathrm{mg} \mathrm{ac}, \mathrm{n}=179)$, metformin (500 mg tid, $n=178)$, nateglinide plus metformin $(n=172)$, or placebo $(\mathrm{n}=172)$. Liquid meal tests were performed at baseline and at week 24 or endpoint, and $\mathrm{HbA}_{1 \mathrm{c}}$ and FPG were measured periodically during the study. Participants were required to have been diagnosed with T2DM at least 3 months before study entry and to have been treated with diet/exercise alone during a 4-week washout period that preceded a 4-week placebo run-in phase. At baseline (week 0), the mean age, BMI, duration of diabetes, $\mathrm{HbA}_{1 \mathrm{c}}$, and FPG of participants were $\sim 58$ years, $29.6 \mathrm{~kg} / \mathrm{m}^{2}, 4.6$ years, $8.4 \%$, and $10.9 \mathrm{mmol} / \mathrm{L}$, respectively, and the 4 treatment groups were well balanced with respect to these baseline characteristics. As illustrated in Figure 1, after 24-week treatment, $\mathrm{HbA}_{1 \mathrm{c}}$ and FPG decreased significantly in each active treatment group and increased modestly in patients receiving placebo, relative to baseline. Postprandial glucose, as assessed by the glucose area under the curve (AUC) during the meal test, decreased in all treatment groups. Thus, relative to placebo, PPG decreased significantly only in the nateglinide monotherapy and in the combination therapy groups. At study endpoint, the placebo-adjusted changes in $\mathrm{HbA}_{1 \mathrm{c}}$ were $-0.9 \%,-1.2 \%$, and $-1.9 \%$ in the nateglinide, metformin, and combination groups, respectively, clearly showing an additive effect of nateglinide and metformin. Metformin monotherapy had a larger effect on FPG $(\Delta=-1.6 \mathrm{mmol} / \mathrm{L})$ than did nateglinide monotherapy $(\Delta=-0.7 \mathrm{mmol} / \mathrm{L})$ but, again, the effects of nateglinide and metformin were additive $(\Delta=-2.4 \mathrm{mmol} / \mathrm{L})$. Moreover, essentially all of the reduction in PPG during combination therapy $(\Delta=-2.5 \mathrm{mmol} / \mathrm{L} \cdot \mathrm{h})$ can be attributed to the effects of nateglinide $(\Delta=-2.1 \mathrm{mmol} / \mathrm{L} \cdot \mathrm{h})$. The most common adverse events (AEs) were suggestive of hypoglycemia and diarrhea. Symptoms suggestive of hypoglycemia occurred most often in the combination group $(26.2 \%)$ and there was no difference between the nateglinide and metformin monotherapy groups $(12.8 \%$ vs $10.1 \%)$. The number of patients with confirmed hypoglycemia (symptoms plus plasma glucose measurement $\leq 3.3 \mathrm{mmol} / \mathrm{L}$ ) was very low -3 patients $(<2 \%)$ in the nateglinide group, $1(<1 \%)$ in the metformin group, and $5(<3 \%)$ in the combination therapy group. Diarrhea was more common in the groups receiving metformin alone $(19.7 \%)$ or in those receiving metformin combined with nateglinide $(14.5 \%)$; these frequencies were 3- to 4-times higher than in the nateglinide monotherapy or placebo groups. Body weight did not change significantly relative to baseline in any treatment group. In summary, this study clearly demonstrated the complementary modes of action of nateglinide and metformin, the additive efficacy of the 2 agents, and a tolerability profile of the combination that did not differ from either of the monotherapy components.

In a subsequent subgroup analysis, Horton et al (2004) assessed the efficacy and tolerability of metformin, nateglinide, and their combination in the subset of patients $(n=401)$ from their earlier trial (Horton et al 2000) who had not been previously exposed to any medication for diabetes. At baseline, the mean disease duration ( 4.0 years), $\mathrm{HbA}_{1 \mathrm{c}}(8.2 \%)$, and FPG $(10.2 \mathrm{mmol} / \mathrm{L})$ in this treatmentnaïve subgroup of patients were slightly less than those in the entire cohort described above. In this drug-naïve group, the patients who received combination therapy for 24 weeks experienced a major reduction in mean $\mathrm{HbA}_{1}$ $(-1.6 \%$ from a mean baseline value of $8.2 \% ; \mathrm{p}<0.0001)$ that was significantly greater than that seen with monotherapy 
Table I Study designs and efficacy outcomes

\begin{tabular}{|c|c|c|c|c|c|c|}
\hline \multirow[t]{2}{*}{ Reference } & \multicolumn{4}{|c|}{ Description of Study } & \multicolumn{2}{|c|}{ Efficacy $\left(\mathrm{HbA}_{\mathrm{Ic}}\right)$} \\
\hline & Duration & $\begin{array}{l}\text { Number of } \\
\text { patients }\end{array}$ & Study design & Treatment groups & $\begin{array}{l}\text { Baseline } \\
\text { (\%) }\end{array}$ & $\begin{array}{l}\text { Endpoint or } \Delta \\
\text { baseline Mean } \pm \\
\text { SE or }[95 \% \mathrm{CI}]\end{array}$ \\
\hline \multirow[t]{4}{*}{$\begin{array}{l}\text { Horton et al } \\
(2000)\end{array}$} & 24 wk & $\begin{array}{l}701 \text { diet- } \\
\text { treated pts }\end{array}$ & $\begin{array}{l}\text { multicenter, double-blind, } \\
\text { parallel-group, RCT }\end{array}$ & $\begin{array}{l}\text { Nateglinide (I } 20 \mathrm{mg} \text { ac) plus } \\
\text { metformin ( } 500 \mathrm{mg} \text { tid) }\end{array}$ & $8.4 \pm 1.1$ & $-1.4 \pm 0.1^{a, b}$ \\
\hline & & & & Nateglinide (I 20 mg ac) & $8.3 \pm 1.0$ & $-0.5 \pm 0 . I^{\mathrm{a}}$ \\
\hline & & & & Metformin (500 mg tid) & $8.4 \pm 1.2$ & $-0.8 \pm 0.1^{a, b}$ \\
\hline & & & & Placebo & $8.3 \pm 1.1$ & $+0.5 \pm 0.1$ \\
\hline \multirow[t]{3}{*}{$\begin{array}{l}\text { Marre et al } \\
(2002)\end{array}$} & 24 wk & $\begin{array}{l}467 \text { metformin- } \\
\text { treated pts }\end{array}$ & $\begin{array}{l}\text { multicenter, double-blind, } \\
\text { parallel-group, RCT }\end{array}$ & $\begin{array}{l}\text { Nateglinide (I } 20 \mathrm{mg} \mathrm{ac} \text { ) added } \\
\text { to metformin (1000 mg bid) }\end{array}$ & 8.2 & $-0.5[-0.6,-0.1]^{\mathrm{a}}$ \\
\hline & & & & $\begin{array}{l}\text { Nateglinide }(60 \mathrm{mg} \mathrm{ac}) \text { added } \\
\text { to metformin }(1000 \mathrm{mg} \text { bid })\end{array}$ & 8.0 & $-0.4[-0.6,-0.1]^{\mathrm{a}}$ \\
\hline & & & & $\begin{array}{l}\text { Placebo added to metformin } \\
\text { (1000 mg bid) }\end{array}$ & 8.3 & 0 \\
\hline \multirow[t]{2}{*}{ French (200I) } & 16 wk & $\begin{array}{l}\text { I92 pts previ- } \\
\text { ously treated with } \\
\text { Glucovance, SU, } \\
\text { or metformin }\end{array}$ & $\begin{array}{l}\text { multicenter, randomized, } \\
\text { parallel-group, open-label } \\
\text { study, following 4-wk } \\
\text { washout from previous } \\
\text { medication }\end{array}$ & $\begin{array}{l}\text { Nateglinide ( } 120 \mathrm{mg} \mathrm{ac} \text { ) added } \\
\text { to metformin (titrated to } \\
1000 \mathrm{mg} \text { bid) }\end{array}$ & $8.2 \pm 1.3$ & $-0.7 \pm 0.1^{a}$ \\
\hline & & & & $\begin{array}{l}\text { Repaglinide (titrated to } \leq 4 \\
\mathrm{mg} \mathrm{ac} \text { ) added to metformin } \\
\text { (titrated to } 1000 \mathrm{mg} \text { bid) }\end{array}$ & $8.4 \pm 1.3$ & $-1.3 \pm 0.1^{a, b}$ \\
\hline $\begin{array}{l}\text { Schatz et al } \\
(2003)\end{array}$ & 3 to $4 \mathrm{mo}$ & $\begin{array}{l}\mid \mathrm{I}, 42 \mathrm{I} \text { metformin- } \\
\text { treated pts }\end{array}$ & $\begin{array}{l}\text { observational study under } \\
\text { general practice condi- } \\
\text { tions }\end{array}$ & $\begin{array}{l}\text { Nateglinide ( } 120 \mathrm{mg} \mathrm{ac} \text { ) added } \\
\text { to ongoing metformin (mean } \\
\text { dose } 850 \mathrm{mg} \text { bid) }\end{array}$ & $8.4 \pm 0.01$ & $7.2 \pm 0.0 \mathrm{I}^{\mathrm{a}}$ \\
\hline \multirow[t]{4}{*}{$\begin{array}{l}\text { Horton et al } \\
(2004)\end{array}$} & 24 wk & 401 drug-naïve pts & $\begin{array}{l}\text { subanalysis of drug- } \\
\text { naïve pts enrolled in a } \\
\text { multicenter, double-blind, } \\
\text { parallel-group, RCT }\end{array}$ & $\begin{array}{l}\text { Nateglinide (I } 20 \mathrm{mg} \text { ac) plus } \\
\text { metformin ( } 500 \mathrm{mg} \text { tid) }\end{array}$ & $8.2 \pm 0.1$ & $-1.6 \pm 0.1^{a, b}$ \\
\hline & & & & Nateglinide (I $20 \mathrm{mg} \mathrm{ac}$ ) & $8.1 \pm 0.1$ & $-0.8 \pm 0.1^{\mathrm{a}}$ \\
\hline & & & & Metformin (500 mg tid) & $8.3 \pm 0.1$ & $-0.8 \pm 0.1^{\mathrm{a}}$ \\
\hline & & & & Placebo & $8.2 \pm 0.1$ & $+0.3 \pm 0.1^{\mathrm{a}}$ \\
\hline \multirow[t]{2}{*}{$\begin{array}{l}\text { Weaver et al } \\
(2004)\end{array}$} & 12 wk & $\begin{array}{l}\text { II } 5 \text { diet-treated } \\
\text { pts, } 214 \text { metformin- } \\
\text { treated pts }\end{array}$ & $\begin{array}{l}\text { multicenter, open-label, } \\
\text { parallel-group study }\end{array}$ & Nateglinide (1 $20 \mathrm{mg}$ ac) & $8.1 \pm 0.06$ & $-0.8 \pm 0.07^{a}$ \\
\hline & & & & $\begin{array}{l}\text { Nateglinide }(120 \mathrm{mg} \mathrm{ac}) \text { added } \\
\text { to metformin }\end{array}$ & $8.1 \pm 0.04$ & $-0.7 \pm 0.05^{\mathrm{a}}$ \\
\hline \multirow[t]{2}{*}{$\begin{array}{l}\text { Gerich et al } \\
(2005)\end{array}$} & $2 y$ & 428 drug-naïve pts & $\begin{array}{l}\text { multicenter, double-blind, } \\
\text { parallel-group, RCT }\end{array}$ & $\begin{array}{l}\text { Nateglinide (120 mg ac) } \\
\text { plus metformin (titrated to } \\
\leq 1000 \mathrm{mg} \text { bid) }\end{array}$ & $8.4 \pm 1.2$ & $-1.4 \pm 0.1^{a}$ \\
\hline & & & & $\begin{array}{l}\text { Glibenclamide (titrated to } \\
\leq 5 \mathrm{mg} \text { bid) plus metformin } \\
\text { (titrated to } \leq 1000 \mathrm{mg} \text { bid) }\end{array}$ & $8.3 \pm 1.1$ & $-1.6 \pm 0.1^{a}$ \\
\hline \multirow[t]{2}{*}{$\begin{array}{l}\text { Ristic et al } \\
(2006)\end{array}$} & 24 wk & $\begin{array}{l}262 \text { pts, } \\
\mathrm{HbA}_{\mathrm{Ic}}=6.8 \%-9.0 \% \\
\text { on metformin } \\
\text { monotherapy }\end{array}$ & $\begin{array}{l}\text { multicenter, double-blind, } \\
\text { parallel-group, RCT }\end{array}$ & $\begin{array}{l}\text { Nateglinide (titrated to } \\
\leq 120 \mathrm{mg} \mathrm{ac} \text { ) added to } \\
\text { metformin ( } \geq 1000 \mathrm{mg} / \mathrm{d})\end{array}$ & $7.7 \pm 0.6$ & $-0.4 \pm 0 . I^{\mathrm{a}}$ \\
\hline & & & & $\begin{array}{l}\text { Gliclazide (titrated to } \\
\leq 240 \mathrm{mg} \text { qd) added to } \\
\text { metformin ( } \geq 1000 \mathrm{mg} / \mathrm{d})\end{array}$ & $7.6 \pm 0.6$ & $-0.6 \pm 0.1^{\mathrm{a}}$ \\
\hline
\end{tabular}


Table I (continued)

\begin{tabular}{|c|c|c|c|c|c|c|}
\hline \multirow[t]{2}{*}{ Reference } & \multicolumn{4}{|c|}{ Description of Study } & \multicolumn{2}{|c|}{ Efficacy (HbAlc) } \\
\hline & Duration & $\begin{array}{l}\text { Number of } \\
\text { patients }\end{array}$ & Study design & Treatment groups & $\begin{array}{l}\text { Baseline } \\
\text { (\%) }\end{array}$ & $\begin{array}{l}\text { Endpoint or } \Delta \\
\text { baseline Mean } \pm \\
\text { SE or }[95 \% \mathrm{Cl}]\end{array}$ \\
\hline \multirow[t]{2}{*}{$\begin{array}{l}\text { Ristic et al } \\
(2007)\end{array}$} & Iy & $\begin{array}{l}213 \text { pts } \mathrm{HbA}_{\mathrm{Ic}}= \\
6.8 \%-9.0 \% \text { on } \\
\text { metformin } \\
\text { monotherapy }\end{array}$ & $\begin{array}{l}\text { 6-mo extension of a 6-mo } \\
\text { multicenter, double-blind, } \\
\text { parallel-group, RCT }\end{array}$ & $\begin{array}{l}\text { Nateglinide (titrated to } \leq \\
120 \mathrm{mg} \mathrm{ac} \text { ) added to } \\
\text { metformin ( } \geq 1000 \mathrm{mg} / \mathrm{d})\end{array}$ & $7.65 \pm 0.6$ & -0.14 \\
\hline & & & & $\begin{array}{l}\text { Gliclazide (titrated to } \leq \\
240 \mathrm{mg} \text { qd) added to } \\
\text { metformin ( } \geq 1000 \mathrm{mg} / \mathrm{d})\end{array}$ & $7.55 \pm 0.6$ & -0.27 \\
\hline \multirow[t]{2}{*}{$\begin{array}{l}\text { Derosa et al } \\
(2007)\end{array}$} & Iy & 248 drug naïve pts & $\begin{array}{l}\text { multicenter, double-blind, } \\
\text { parallel-group, } \mathrm{RCT}\end{array}$ & $\begin{array}{l}\text { Nateglinide and metformin } \\
\text { (titrated to I } 20 \mathrm{mg} \text {, ac; } \\
\text { I000 mg, tid) }\end{array}$ & $8.1 \pm 1.0$ & $6.4 \pm 0.4^{\mathrm{a}, \mathrm{b}}$ \\
\hline & & & & $\begin{array}{l}\text { Glibenclamide and } \\
\text { metformin (titrated to } \\
5 \mathrm{mg} \text { tid, } 1000 \mathrm{mg} \text {, tid) }\end{array}$ & $8.2 \pm 1.1$ & $7.3 \pm 0.6^{\mathrm{a}}$ \\
\hline \multirow[t]{2}{*}{$\begin{array}{l}\text { Schwarz et al } \\
(2008)\end{array}$} & $2 y$ & $\begin{array}{l}66 \text { drug-naïve pts } \\
\text { age } \geq 65 \text { y }\end{array}$ & $\begin{array}{l}\text { subanalysis of elderly } \\
\text { patients enrolled in } \\
\text { multicenter, double-blind, } \\
\text { parallel-group, RCT }\end{array}$ & $\begin{array}{l}\text { Nateglinide and metformin } \\
\text { (titrated to I } 20 \mathrm{mg} \text {, ac; } \\
\text { I000 mg, bid) }\end{array}$ & $7.8 \pm 0.2$ & $6.6 \pm 0.1^{\mathrm{a}}$ \\
\hline & & & & $\begin{array}{l}\text { Glibenclamide and } \\
\text { metformin (titrated to } \\
5 \mathrm{mg} \text { bid; } 1000 \mathrm{mg} \text {, bid) }\end{array}$ & $7.7 \pm 0.1$ & $6.5 \pm 0.1^{\mathrm{a}}$ \\
\hline
\end{tabular}

${ }^{\mathrm{a}} \mathrm{p}<0.05$ or better vs baseline; ${ }^{\mathrm{b}} \mathrm{p}<0.05$ or better vs comparator.

Abbreviations: RCT, randomized, controlled trial; $\mathrm{HbAlc}$ glycosylated hemoglobin.

$(-0.8 \%$ for both treatments), or with placebo treatment $(+0.3 \%)$. Thus, the placebo-adjusted change in $\mathrm{HbA}_{1 \mathrm{c}}$ in drug-naïve patients receiving initial combination therapy with nateglinide and metformin was $-1.9 \%$, and of the patients receiving initial combination therapy, $70 \%$ achieved an endpoint $\mathrm{HbA}_{1 \mathrm{c}}$ of $<7 \%$ compared with $34 \%, 41 \%$, and $17 \%$ in the groups receiving nateglinide monotherapy, metformin monotherapy, and placebo, respectively. All active treatments also resulted in significant reductions in FPG $(\Delta=-1.1,-1.2,-2.3$, and $+0.2 \mathrm{mmol} / \mathrm{L})$ and in PPG excursions $(\Delta=-1.9,-1.0,-2.3$, and $-0.5 \mathrm{mmol} / \mathrm{L})$ for nateglinide, metformin, combination, and placebo groups, respectively. The AE profile in this drug-naïve subgroup of patients was very similar to that seen in the whole cohort (described above). Marre et al (2002) evaluated the effect of nateglinide as an add-on to high-dose metformin in patients with T2DM. This 24-week, double-blind, parallelgroup RCT included 467 patients with T2DM treated with metformin monotherapy for $\geq 3$ months who had been stabilized on metformin $\geq 1500 \mathrm{mg}$ daily for at least 4 weeks prior to study entry. After a 4-week run-in during which all patients received metformin at a dose of 1000 mg bid, patients were randomized to receive nateglinide
(60 mg ac, $\mathrm{n}=155$ ), nateglinide (120 mg ac, $\mathrm{n}=160$ ), or placebo $(n=152)$ added to the ongoing metformin $(1000$ mg bid) monotherapy.

At baseline, the mean age, BMI, duration of diabetes, $\mathrm{HbA}_{1 \mathrm{c}}$, and FPG in the whole cohort were $\sim 57$ years, $29.4 \mathrm{~kg} / \mathrm{m}^{2}, 8.1 \%$, and $9.9 \mathrm{mmol} / \mathrm{L}$, respectively. The treatment groups were well balanced with respect to these baseline characteristics.

Addition of nateglinide at either dose to metformin resulted in a significant reduction of $\mathrm{HbA}_{1 \mathrm{c}}$ compared with metformin plus placebo. The placebo-corrected reductions in $\mathrm{HbA}_{1 \mathrm{c}}$ were $-0.4 \%$ and $-0.6 \%$ in the nateglinide 60 -mg and nateglinide 120-mg groups, respectively. Larger, but still dose-related reductions were seen in patients with higher baseline $\mathrm{HbA}_{1 \mathrm{c}}$ levels; in the subgroup of patients with a baseline value between $8 \%$ and $9.5 \%$, the $\Delta \mathrm{HbA}_{1 \mathrm{c}}$ was $-0.5 \%$ for the $60-\mathrm{mg}$ dose and $-0.8 \%$ for the 100 $\mathrm{mg}$ dose. In the subgroup of patients with baseline level $>9.5 \%$, the $\Delta \mathrm{HbA}_{1 \mathrm{c}}$ was $-0.8 \%$ and $-1.4 \%$ for nateglinide $60 \mathrm{mg}$ and $100 \mathrm{mg}$, respectively, while with placebo added to metformin $\mathrm{HbA}_{1 \mathrm{c}}$ changed by less than $0.1 \%$ in all subgroups of patients. Both doses of nateglinide also resulted in modest but significant reductions in FPG compared to 


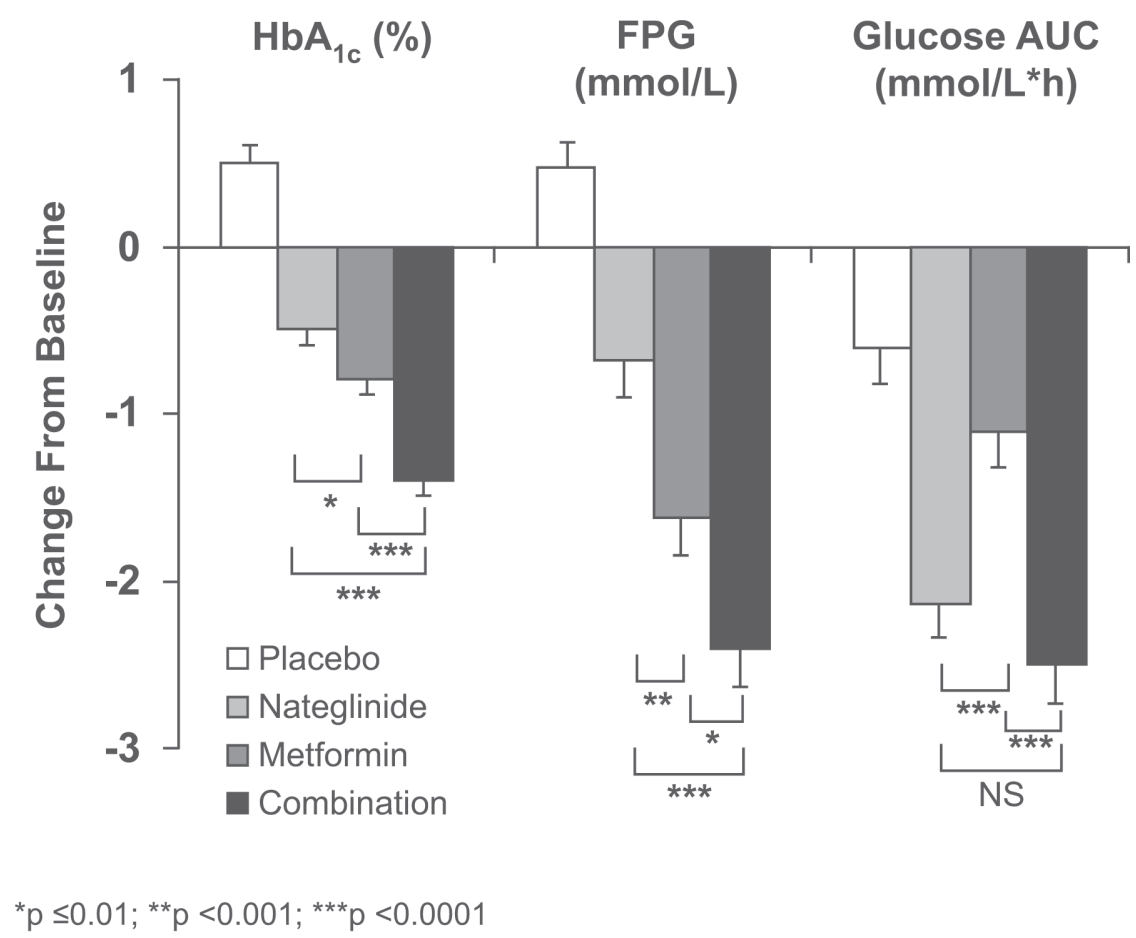

Figure I Adjusted mean change from baseline in glycosylated hemoglobin ( $\mathrm{HbA}_{\mathrm{lc}}$ ), fasting plasma glucose (FPG), and glucose area under the curve (AUC) after Sustacal challenge. All parameters were significantly reduced from baseline $(\mathrm{p} \leq 0.000 \mathrm{I})$ in the active treatment groups. All values were significantly reduced compared to placebo ( $\mathrm{p} \leq 0.000 \mathrm{I}$ ) except for glucose AUC with metformin monotherapy (not significant, NS). ${ }^{*} \mathrm{p} \leq 0.0 \mathrm{I} ;{ }^{* *} \mathrm{p} \leq 0.00 \mathrm{I}$; *** $\leq 0.000 \mathrm{I}$. Open bars $=$ placebo; light gray bars $=$ nateglinide monotherapy; dark gray bars = metformin monotherapy; black bars = nateglinide plus metformin (Horton et al 2000). Copyright @ 2000 American Diabetes Association. From Diabetes Care ${ }^{\circledR}$,Vol 23, 2000; 1660-1665. Reprinted with permission from The American Diabetes Association.

placebo when added to metformin. Addition of $60-\mathrm{mg}$ nateglinide to metformin had no effect on body weight, while treatment with $120-\mathrm{mg}$ nateglinide plus metformin resulted in a $0.9-\mathrm{kg}$ weight gain compared with treatment with metformin plus placebo.

The overall percentage of patients experiencing AEs was similar in all treatment groups $(54.6 \%, 60 \%$, and $58.8 \%$ in the metformin/placebo group, the metformin/nateglinide 60-mg group, and the metformin/nateglinide 120-mg group, respectively). The most commonly reported AEs were symptoms suggestive of hypoglycemia $(3.9 \%, 8.4 \%$, and $15.6 \%$, respectively). When stratified by $\mathrm{HbA}_{1 \mathrm{c}}$ level, most symptoms suggestive of hypoglycemia occurred with nateglinide 120 $\mathrm{mg} / \mathrm{metformin}$ administered to patients with low baseline $\mathrm{HbA}_{1 \mathrm{c}}(\leq 8 \%)$. Although a blood glucose level was recorded in $80 \%$ of the events, very few patients $(n=6,1.1 \%)$ had confirmed hypoglycemia, defined as a symptomatic event with a plasma glucose equivalent $\leq 3.3 \mathrm{mmol} / \mathrm{L}$, and none of these hypoglycemic episodes required intervention by a third party. As expected, since patients had been stabilized on metformin monotherapy for $\geq 3$ months prior to study, the incidence of gastrointestinal AEs was low and similar in all treatment groups.
A 2-year study of initial combination therapy (PRESERVE- $\beta$ ) compared the effects of nateglinide plus metformin (nate/met) to those of glyburide plus metformin (glyb/met) in drug-naïve patients with relatively recently diagnosed T2DM (Gerich et al 2005). In this double-blind, parallel-group, RCT, 428 patients received open-label metformin $(500 \mathrm{mg}$ qd titrated to $1000 \mathrm{mg}$ bid if tolerated) combined with either nateglinide (120 mg ac, $\mathrm{n}=219)$ or glyburide $(1.25 \mathrm{mg}$ qd titrated to a maximum of $5 \mathrm{mg}$ bid, $\mathrm{n}=209$ ). Blinding was achieved by use of matching placebo for nateglinide and glyburide. At baseline, the mean age, BMI, disease duration, $\mathrm{HbA}_{1 \mathrm{c}}$, and FPG were $\sim 53$ years, $33.4 \mathrm{~kg} / \mathrm{m}^{2}$, 1.8 years, $8.4 \%$, and $10.0 \mathrm{mmol} / \mathrm{L}$, respectively. The treatment groups were well balanced with respect to these baseline characteristics.

As illustrated in Figure 2, both drug combinations produced substantial and sustained reductions in $\mathrm{HbA}_{1 \mathrm{c}}$. At study endpoint, the mean $\Delta \mathrm{HbA}_{1 \mathrm{c}}$ was $-1.2 \%$ in the nate/met group and $-1.5 \%$ in the glyb/met group ( $p<0.0001$ vs baseline for both groups, $p=0.1730$ between groups). After 2 years of treatment, $39 \%$ of the nate/met group and $43 \%$ of the glyb/met group had achieved and maintained $\mathrm{HbA}_{1 \mathrm{c}}<7 \%$. 


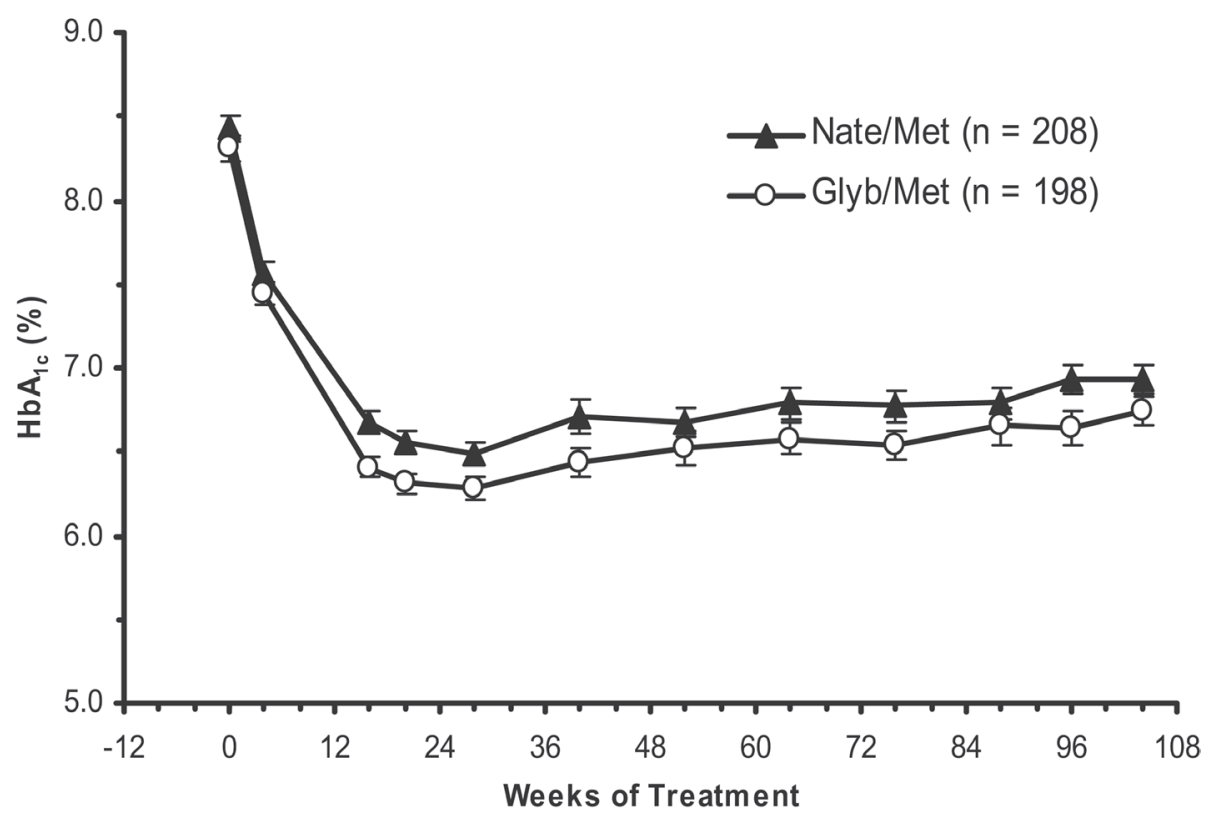

Figure 2 Time course of $\mathrm{HbA}_{1 c}$ in drug-naïve patients with type 2 diabetes randomized to the nateglinide/metformin combination (closed triangles) or the glyburide/metformin combination (open circles). Mean \pm SE, intention-to-treat population (Gerich et al 2005). Copyright @ 2005 American Diabetes Association. From Diabetes Care ${ }^{\circledR}, V o l$ 28, 2005; 2093-2099. Reprinted with permission from The American Diabetes Association.

Consistent with their known mechanisms of actions and established effects on FPG and PPG, glyb/met was more effective in reducing FPG, and nate/met was more effective in reducing PPG. Thus, FPG was reduced by $1.6 \mathrm{mmol} / \mathrm{L}$ and $2.4 \mathrm{mmol} / \mathrm{L}$ after 104 weeks of treatment with nate/met and glyb/met, respectively ( $p<0.0001$ vs baseline for both groups, $p$ $<0.008$ between groups), whereas PPG excursions, as assessed by the incremental $\mathrm{AUC}_{0-120 \mathrm{~min}}$ during an oral glucose tolerance test (OGTT), was reduced by $94 \mathrm{mmol} / \mathrm{L} \cdot \mathrm{min}$ and $57 \mathrm{mmol} /$ $\mathrm{L} \cdot \mathrm{min}$ after 104 weeks of treatment with nate/met and glyb/met, respectively ( $p<0.0001 \mathrm{vs}$ baseline for nate/met, $\mathrm{p}=0.0112 \mathrm{vs}$ baseline for glyb/met, $\mathrm{p}=0.0592$ between groups).

Most of the AEs seen during the 2-year treatment period were those that would be expected to occur in an aging, overweight population (eg, arthralgia [10.5\% of both treatment groups], or hypertension [ $8.7 \%$ nate $/$ met, $14.8 \% \mathrm{glyb} / \mathrm{met}]$ ). The only common $(>10 \%)$ AE that occurred predominantly (more than 2-fold difference in prevalence) in either treatment group was hypoglycemia, which was reported by $8.2 \%$ of the patients receiving nate/met and $17.7 \%$ of the patients receiving glyb/met $(\mathrm{p}=0.003)$. The only serious AE suspected to be related to treatment was severe hypoglycemia that occurred in 2 patients receiving glyb/met. During 2-year treatment, there was a statistically significant change in body weight between the groups. There was a modest increase in body weight in patients receiving glyb/met $(\Delta=+0.8 \mathrm{~kg})$ and a small decrease in weight in patients receiving nate $/$ met $(\Delta=-0.4 \mathrm{~kg}, \mathrm{p}=0.0115 \mathrm{vs}$ glyb $/$ met $)$.
Another publication recently reported results from the subgroup of participants in PRESERVE- $\beta$ who were aged $\geq 65$ years of age (Schwarz et al 2008). This elderly subpopulation comprised 66 patients (33 patients in each treatment group), with a mean age, BMI, diabetes duration, $\mathrm{HbA}_{1 \mathrm{c}}$, and $\mathrm{FPG}$ of $\sim 70$ years, $32 \mathrm{~kg} / \mathrm{m}^{2}, 2.1$ years, $7.8 \%$, and $158 \mathrm{mg} / \mathrm{dL}$, respectively. The elderly patients receiving glyb/met were somewhat more obese and had a somewhat longer duration of known diabetes than did the elderly patients receiving nate $/ \mathrm{met}\left(\mathrm{BMI}=33.5 \mathrm{~kg} / \mathrm{m}^{2}\right.$ vs $30.4 \mathrm{~kg} / \mathrm{m}^{2}$, disease duration $=2.5$ vs 1.7 years). After 2 years of treatment, the change from baseline in $\mathrm{HbA}_{1 \mathrm{c}}$ was $-1.2 \%$ in both treatment groups ( $p<0.001$ vs baseline for both treatments, $p=0.310$ between treatments). Fourteen of $20(70 \%)$ elderly patients completing 2 years of nate/met combination therapy maintained $\mathrm{HbA}_{1 \mathrm{c}}<7 \%$, as did 13 of $20(65 \%)$ elderly patients completing 2 years of $\mathrm{glyb} / \mathrm{met}$ combination therapy. The change from baseline in FPG at study endpoint was $-26 \mathrm{mg} / \mathrm{dL}$ and $-36 \mathrm{mg} / \mathrm{dL}$ in patients receiving nate/met and glyb/met, respectively ( $p<0.001$ vs baseline for both treatments, $p=0.234$ between treatments). The mean change in the PPG excursion, as assessed by the incremental $\mathrm{AUC}_{0-120 \min }$ during OGTT, approached statistical significance in the nate/met group $(\Delta=-100 \mathrm{mmol} / \mathrm{L} \cdot \mathrm{min}, \mathrm{p}=0.071$ vs baseline $)$ but was considerably less in patients receiving glyb/met $(\Delta=-53 \mathrm{mmol} / \mathrm{L} \cdot \mathrm{min}, \mathrm{p}=0.385 \mathrm{vs}$ baseline $)$. 
The overall AE profiles in the 2 treatment groups were very similar except for the incidence of hypoglycemia, which was significantly greater with glyb/met than with nate/met $(p=0.023)$. One incident of mild hypoglycemia occurred in one elderly patient receiving nate/met, while 1 hypoglycemic episode occurred in each of 8 elderly patients receiving glyb/met; 4 were considered mild, 3 were considered moderate, and 1 was severe and led to discontinuation from the study.

Another blinded RCT compared the efficacy and safety of nateglinide and gliclazide when added to metformin in patients with inadequate glycemic control $\left(\mathrm{HbA}_{1 \mathrm{c}}\right.$ between $6.8 \%$ and $9.0 \%$ ) on metformin monotherapy (Ristic et al 2006). This 24-week, double-blind, double-dummy parallel-group study randomized 262 patients with T2DM, diagnosed at least 6 months previously, receiving metformin monotherapy for at least 3 months, at their individually maximum tolerated dose ( $\geq 1000 \mathrm{mg}$ daily) for at least 2 months. Patients were also randomized to receive starting doses of nateglinide $(60 \mathrm{mg}$ ac, $n=133$ ) or gliclazide ( $80 \mathrm{mg} \mathrm{qd}, \mathrm{n}=129)$, which were up-titrated monthly for the first 3 months if FPG $<7 \mathrm{mmol} / \mathrm{L}$, to maximum doses of $180 \mathrm{mg}$ ac for nateglinide or $240 \mathrm{mg}$ qd for gliclazide. At baseline, the mean age, BMI, duration of diabetes, $\mathrm{HbA}_{1 \mathrm{c}}$, and FPG were $\sim 62$ years, $30 \mathrm{~kg} / \mathrm{m}^{2}, 6.9$ years, $7.6 \%$, and $8.8 \mathrm{mmol} / \mathrm{L}$, respectively, and the treatment groups were well balanced with respect to these baseline characteristics. At week 24 or study endpoint, the least squares mean change from baseline in $\mathrm{HbA}_{1 \mathrm{c}}$ was $-0.41 \%$ in patients receiving nateglinide and $-0.57 \%$ in those receiving gliclazide ( $p<0.001$ vs baseline for both groups, $p=0.099$ between groups). At study endpoint, $35 \%$ of patients receiving nateglinide added to metformin and $47 \%$ of those receiving gliclazide added to metformin achieved $\mathrm{HbA}_{1 \mathrm{c}}<7 \%$. The decrease in FPG in patients receiving gliclazide $(\Delta=-0.8 \mathrm{mmol} / \mathrm{L}$, $\mathrm{p}<0.001$ vs baseline) was somewhat greater than that in patients receiving nateglinide $(\Delta=-0.6 \mathrm{mmol} / \mathrm{L}, \mathrm{p}<0.001$ vs baseline), but this difference was not statistically significant $(p=0.375)$. In contrast, PPG, as assessed by the maximum PPG excursion, was significantly decreased only in the nateglinide group $(\Delta=-0.7 \mathrm{mmol} / \mathrm{L}[\mathrm{p}=0.001]$ and $-0.1 \mathrm{mmol} / \mathrm{L}$ $[\mathrm{p}=0.663]$ for nateglinide and gliclazide, respectively, $\mathrm{p}=0.037$ between groups).

The incidence of suspected drug-related AEs was low and similar in the 2 groups $(6.9 \%$ and $7.1 \%$ for nateglinide and gliclazide, respectively). The percentages of patients with at least one AE suggestive of hypoglycemia $(-25 \%)$ or with at least one confirmed hypoglycemic event $(\sim 22 \%)$ were very similar in the 2 treatment groups. However, the percentage of patients with $\geq 3$ confirmed hypoglycemic events was somewhat higher with gliclazide (12.7\%) than with nateglinide $(9.2 \%)$. It should be noted that the plasma glucose cutoff for confirmed hypoglycemia $(>4.0 \mathrm{mmol} / \mathrm{L})$ was higher in this study than in previously described studies.

Results from a 6-month extension of the study described above (Ristic et al 2006) were reported recently (Ristic et al 2007). A total of 120 patients in the nateglinide group and 109 patients in the gliclazide group completed the study, and most of these patients continued with the double-blind extension (112 patients [93.3\%] in the nateglinide group and 101 patients $[89.1 \%]$ in the gliclazide group). Glycemic control appeared to deteriorate somewhat during the 6-month extension, but qualitatively, the 1-year results mirrored the 6-month results. There was no significant difference between treatment regimens in the $\Delta \mathrm{HbA}_{1 \mathrm{c}}$ from baseline to week $52(-0.14 \%$ for nateglinide and -0.27 for gliclazide, $p=0.396$ between groups); $40 \%$ of patients receiving nateglinide plus metformin and $47.5 \%$ of those receiving gliclazide plus metformin achieved endpoint $\mathrm{HbA}_{1 \mathrm{c}}<7 \%$. The $\Delta \mathrm{FPG}$ was somewhat greater in the gliclazide group $(\Delta=-0.7 \mathrm{mmol} / \mathrm{L}, \mathrm{p}=0.003$ vs baseline) than in the nateglinide group $(\Delta=-0.2 \mathrm{mmol} / \mathrm{L}$, $\mathrm{p}=0.357$ vs baseline), but the between-treatment difference was not statistically significant $(p=0.096)$. The change from baseline in the maximum PPG excursion was somewhat greater with nateglinide $(\Delta=-0.7 \mathrm{mmol} / \mathrm{L}, \mathrm{p}=0.087$ vs baseline) than with gliclazide ( $\Delta=-0.3 \mathrm{mmol} / \mathrm{L}, \mathrm{p}=0.500$ vs baseline), but, again, the between-treatment difference was not significant $(\mathrm{p}=0.470)$.

The AE profiles were similar in the 2 treatment groups during the extension, and a similarly low percentage of patients receiving natgelinide $(6.3 \%)$ or gliclazide $(6.9 \%)$ experienced $\geq 3$ confirmed episodes of hypoglycemia. There was a statistically significant increase in body weight during the 52 weeks of study in patients receiving gliclazide plus metformin $(\Delta=0.9 \mathrm{~kg}, \mathrm{p}=0.009 \mathrm{vs}$ baseline $)$; the change in body weight in the nateglinide plus metformin group was $0.4 \mathrm{~kg}$ and not statistically significant ( $p=0.201$ vs baseline).

Results from a 1-year, double-blind, parallel-group RCT comparing initial combination therapy with nateglinide plus metformin (nate/met) vs glibenclamide plus metformin (glyb/met) were published recently (Derosa et al 2007). This study enrolled 248 treatment-naïve patients with T2DM diagnosed at least 6 months previously, who were overweight (BMI $25 \mathrm{~kg} / \mathrm{m}^{2}$ to $28 \mathrm{~kg} / \mathrm{m}^{2}$ ) and hypertensive $(\geq 130 / 85 \mathrm{mmHg}$ ). During the first month, patients received either nateglinide $(60 \mathrm{mg}$ ac, $\mathrm{n}=122$ ) or glibenclamide (2.5 mg tid, $\mathrm{n}=126$ ). Metformin (500 mg tid) was added 
during the second month of treatment in both groups of patients, and during the subsequent 4 months both metformin and the insulinotropic agent were up-titrated to maximum daily doses of nateglinide (360 mg, $120 \mathrm{mg} \mathrm{ac}$ ) or glibenclamide (15 mg, $5 \mathrm{mg}$ tid) plus metformin (3000 $\mathrm{mg}, 1000 \mathrm{mg}$ tid) if tolerated. The mean daily doses of nateglinide, glibenclamide, and metformin during the final 6 months of study were $300 \pm 60 \mathrm{mg}, 12.5 \pm 2.5 \mathrm{mg}$, and 2500 $\pm 500 \mathrm{mg}$, respectively, with 119 patients receiving nate/met and 114 patients receiving glyb/met. Assessments of $\mathrm{HbA}_{1 \mathrm{c}}$, FPG, 2-hour PPG (after lunch), fasting lipids, blood pressure, and several prothrombotic factors were made periodically during the 12 months of treatment.

At baseline, the mean age, BMI, duration of diabetes, $\mathrm{HbA}_{1 \mathrm{c}}$, and FPG were $\sim 56$ years, $26.5 \mathrm{~kg} / \mathrm{m}^{2}, 4.5$ years, $8.2 \%$, and $176 \mathrm{mg} / \mathrm{dL}$, respectively, and the treatment groups were well-balanced with respect to these baseline characteristics. As summarized in Table 2, 1-year treatment of overweight, hypertensive, drug-naïve patients with T2DM with nate/met as initial combination therapy significantly decreased $\mathrm{HbA}_{1 \mathrm{c}}$ ' FPG, and PPG as well as lipoprotein (a) (Lp[a]), plasminogen activator inhibitor-1 (PAI-1), and homocysteine levels relative to baseline. In patients receiving the glyb/met combination, a significant decrease from baseline in $\mathrm{HbA}_{1 \mathrm{c}}, \mathrm{FPG}$, and PPG was also seen after 12-month treatment; however, the improvement in $\mathrm{HbA}_{1 \mathrm{c}}$ was significantly less with glyb/met than with nate/met, and glyb/met had no significant effect on any prothrombotic factor. Neither treatment significantly affected any fasting lipid parameter, blood pressure, or BMI. No safety or tolerability assessments were reported, nor were the percentages of patients achieving endpoint $\mathrm{HbA}_{1 \mathrm{c}}<7 \%$. However, because the mean endpoint $\mathrm{HbA}_{1 \mathrm{c}}$ with nate/met was $6.4 \%$ - while this was $7.3 \%$ in patients receiving glyb/ met - it may be inferred that a substantially higher percentage of patients receiving nate/met than glyb/met achieved this glycemic target.

\section{Open-label trials}

In addition to the blinded, RCTs of combination therapy with metformin and nateglinide, 3 open-label studies of this combination have also been reported. Schatz et al (2003) conducted a general practice observation study that followed 11,476 patients with T2DM who were treated with nateglinide and metformin for 3 to 4 months (mean observation period $=96$ days $)$. The recommended dose of nateglinide was $120 \mathrm{mg}$ before each principal meal. No recommended daily dose of metformin was provided, but the most common metformin regimen used in Germany, where this study was conducted, is $850 \mathrm{mg}$ bid. The mean age, $\mathrm{BMI}$, and $\mathrm{HbA}_{1 \mathrm{c}}$ of patients in the study were 61.1 years, $29.4 \mathrm{~kg} / \mathrm{m}^{2}$, and $8.4 \%$, respectively. Nearly all participants (98\%) were already taking metformin when nateglinide was added. After the addition of nateglinide to metformin, mean $\mathrm{HbA}_{1 \mathrm{c}}$ was reduced to $7.2 \%$ ( $\mathrm{p}<0.0001$ vs baseline) and, as expected, there was a direct relationship between the baseline value and the magnitude of reduction in $\mathrm{HbA}_{1 \mathrm{c}}$ over the course of treatment. At baseline, only $11.1 \%$ of the patients had $\mathrm{HbA}_{10}$ $\leq 7 \%$, but by the end of the treatment period $47.7 \%$ of patients had achieved this goal. PPG was also measured following a standardized breakfast or during an OGGT. During the treatment period, mean 2-hour PPG decreased from $210 \mathrm{mg} / \mathrm{dL}$ to $152 \mathrm{mg} / \mathrm{dL}(\mathrm{p}<0.0001)$.

Addition of nateglinide to metformin was also associated with significant improvement in both diastolic and systolic blood pressure and resulted in a small $(1.5 \mathrm{~kg})$ but significant reduction in body weight. Overall, AEs were reported in 277 patients $(2.9 \%)$ and severe AEs in 56 patients $(0.5 \%)$. Hypoglycemic episodes were seen in 30 patients $(0.3 \%)$.

Table 2 Effects of initial combination therapy with nateglinide (Nate) or glibenclamide (Glyb) plus metformin (Met) on glycemic control and prothrombotic factors during I-year treatment of overweight and hypertensive patients with type 2 diabetes (Derosa et al 2007)

\begin{tabular}{|c|c|c|c|c|}
\hline \multirow[b]{2}{*}{ Mean \pm SD } & \multicolumn{2}{|l|}{ Nate/Met } & \multicolumn{2}{|l|}{ Glyb/Me } \\
\hline & Baseline & 12 months & Baseline & 12 months \\
\hline $\mathrm{HbA}_{\mathrm{Ic}}(\%)$ & $8.1 \pm 1.0$ & $6.4 \pm 0.4^{b, c}$ & $8.2 \pm 1.1$ & $7.3 \pm 0.6^{\mathrm{a}}$ \\
\hline FPG (mg/dL) & $|74 \pm 2|$ & $138 \pm 17^{b}$ & $177 \pm 24$ & $136 \pm 15^{b}$ \\
\hline 2-hour PPG (mg/dL) & $191 \pm 28$ & $150 \pm 2 I^{b}$ & $187 \pm 24$ & $166 \pm 20^{a}$ \\
\hline Lp(a) (mg/dL) & $29.3 \pm 18.9$ & $20.1 \pm 14.2^{a, c}$ & $28.5 \pm 17.4$ & $26.7 \pm 16.9$ \\
\hline PAI-I (ng/mL) & $44.5 \pm 15.9$ & $36 .| \pm| 3 .\left.\right|^{a, c}$ & $43.9 \pm 16.2$ & $41.3 \pm 15.6$ \\
\hline Homocysteine $(\mu \mathrm{M})$ & $13.6 \pm 2.4$ & $9.2 \pm 1.8^{\mathrm{a}, \mathrm{c}}$ & $13.9 \pm 2.6$ & $12.7 \pm 2.2$ \\
\hline
\end{tabular}

${ }^{\mathrm{a}} \mathrm{p}<0.05$ vs baseline, ${ }^{\mathrm{b}} \mathrm{p}<0.01$ vs baseline, ${ }^{\mathrm{c}} \mathrm{p}<0.05$ vs glib/met.

Abbreviations: Nate, nateglinide; Glyb, glibenclamide; Met, metformin;FPG, fasting plasma glucose; PPG, postprandial glucose; Lp(a), lipoprotein (a); PAI-I, plasminogen activator inhibitor-I; $\mathrm{HbA}_{\mathrm{Ic}}$ glycosylated hemoglobin. 
In an open-label, randomized, parallel-group, multicenter study, Raskin et al (2003) compared the efficacy and safety of nateglinide and repaglinide when added to metformin. Enrolled patients $(\mathrm{N}=192)$ had diagnosed T2DM for at least 3 months and had $\mathrm{HbA}_{1 \mathrm{c}}$ values $>7 \%$ and $\leq 12 \%$ during previous monotherapy with sufonylurea, metformin, or lowdose glyburide/metformin. During a 4-week run-in period, all patients previously taking sulfonylurea or glyburide/ metformin were switched to metformin. All patients on metformin were titrated to a maximum dose of $1000 \mathrm{mg}$ bid and then randomized to receive either nateglinide (120 $\mathrm{mg} \mathrm{ac})$ or repaglinide ( $1 \mathrm{mg}$ ac titrated to a maximum of $4 \mathrm{mg} \mathrm{ac}$ ). After the 2-week titration period, the combination therapies were continued for an additional 14 weeks.

At baseline, the mean age, BMI, disease duration, $\mathrm{HbA}_{1 \mathrm{c}}$, and FPG were 55.4 years, $33.2 \mathrm{~kg} / \mathrm{m}^{2}, 6.9$ years, $8.3 \%$, and $190 \mathrm{mg} / \mathrm{dL}$, respectively. The groups were well balanced with respect to age, BMI, and FPG, but the mean disease duration was somewhat longer in patients randomized to nateglinide/metformin (7.1 years) than in those randomized to repaglinide/metformin (6.7 years) and $\mathrm{HbA}_{1 \mathrm{c}}$ was somewhat higher in the repaglinide/metformin group (8.4\%) than in the nateglinide/metformin group (8.2\%).

The mean change from baseline in $\mathrm{HbA}_{1 \mathrm{c}}$ was $-1.3 \%$ with repaglinide and $-0.7 \%$ with nateglinide added to metformin ( $p<0.001$ between groups). At study endpoint, $59 \%$ of patients receiving repaglinide and $47 \%$ of those receiving nateglinide achieved $\mathrm{HbA}_{1 \mathrm{c}} \leq 7 \%$. The mean decrease in FPG was also significantly greater with repaglinide/metformin than with nateglinide/metformin $(-39 \mathrm{mg} / \mathrm{dL}$ vs $-21 \mathrm{mg} / \mathrm{dL}$, $\mathrm{p}=0.002$ ). However, the mean reductions in PPG did not differ between groups.

Hypoglycemic episodes were reported by $7 \%$ of patients receiving repaglinide/metformin and by $2 \%$ of those receiving nateglinide/metformin. However, no severe hypoglycemia occurred in either group. Otherwise, there were no noteworthy differences in the AE profiles in the 2 treatment groups. The mean change in body weight was $+0.6 \mathrm{~kg}$ with repaglinide/metformin and $-0.5 \mathrm{~kg}$ with nateglinide/ metformin (statistical significance not reported).

It should be noted that the generalizability of the conclusions drawn by Raskin et al (2003) has been questioned because of limitations of the study design (Baron 2003). These include the fact that metformin was titrated to the final dose ( $2 \mathrm{~g}$ /day) over only 4 weeks, which may not be an adequate time for glycemic control to stabilize and to establish a reliable baseline. Another limitation is that more than $33 \%$ of patients receiving nateglinide/metformin had previously been treated with a sulfonylurea. Sulfonylureas are known to blunt the efficacy of nateglinide; at the time of this study, the nateglinide label stated that patients should not be switched from a sulfonylurea to nateglinide. Thus, a substantial proportion of patients in the nateglinide/metformin group was treated outside of the product labeling.

Another open-label, 12-week study included a group of patients who received nateglinide (120 mg ac, $\mathrm{n}=214)$ added to a stable dose of metformin (Weaver et al 2004). At baseline, mean age, $\mathrm{BMI}$, duration of known diabetes, $\mathrm{HbA}_{1 \mathrm{c}}$, and FPG were $\sim 60$ years (range $=37-84$ years), $32.6 \mathrm{~kg} / \mathrm{m}^{2}$, 5 years, $8.1 \%$, and $10.0 \mathrm{mmol} / \mathrm{L}$, respectively. The changes from baseline to week 12 of treatment with nateglinide added to ongoing metformin monotherapy in $\mathrm{HbA}_{1 \mathrm{c}}$, FPG, and 2-hour PPG averaged $-0.7 \% \mathrm{mmol} / \mathrm{L},-0.8 \mathrm{mmol} / \mathrm{L}$, and $-2.4 \mathrm{mmol} / \mathrm{L}$, respectively ( $\mathrm{p}<0.0001$ vs baseline for each efficacy parameter). Only $2 \%$ of patients who received nateglinide added to metformin had $\mathrm{HbA}_{1 \mathrm{c}}<7 \%$ at baseline, while $34 \%$ achieved this goal after 12 weeks' treatment.

In patients receiving nateglinide added to metformin, $14 \%$ experienced symptoms consistent with hypoglycemia, but no confirmatory glucose measurements were reported. None of the suspected hypoglycemic episodes required assistance from an outside party. Serious AEs were reported by 3 patients (1.4\%), but only 1 of these was suspected to be related to study medication. The authors concluded that nateglinide added to metformin was safe and effective in patients up to 84 years of age.

\section{Summary and conclusions}

T2DM is difficult to control with a single oral agent and the rate of monotherapy failure is high, so combination therapy with complementary classes of drugs that act on different aspects of glycemic control would be expected to be an effective strategy. The present work reviewed all published information about the efficacy and safety/tolerability of nateglinide when combined with metformin in patients with T2DM, whether given as initial combination therapy or as an add-on to ongoing metformin monotherapy. Because metformin acts by suppressing excessive HGP and improving glucose clearance, its predominant effect is to decrease FPG. Nateglinide, which is taken before main meals, serves to restore the early phase of insulin release that is lost relatively soon after the onset of diabetes, and thus limits PPG excursions that have been implicated in the cardiovascular risk associated with T2DM.

Both metformin and nateglinide are known to have a low propensity to elicit hypoglycemia. The known side effects of metformin (ie, gastrointestinal symptoms such as diarrhea 
and abdominal discomfort) generally occur only early in the course of treatment and can be minimized by dose titration. Nateglinide has an excellent safety and tolerability profile and does not require dose titration. Accordingly, it is not surprising that the published literature supports a conclusion that these drugs, when combined, are safe, well tolerated, and produce a degree of long-term glycemic control that is not achievable with either agent alone. The largest decreases in $\mathrm{HbA}_{1 \mathrm{c}}(\Delta=-1.4 \%$ to $-1.9 \%$, sustained for up to 2 years) are seen in drug-naïve patients given metformin ( $\geq 1500 \mathrm{mg} /$ day) and nateglinide $(120 \mathrm{mg} \mathrm{ac})$ as initial combination therapy. Lesser, but still clinically-significant decreases $(\Delta=-0.5 \%$ to $-1.2 \%$ ) are seen when nateglinide is added to ongoing stable metformin monotherapy. With either of these approaches, the decrease in $\mathrm{HbA}_{1 \mathrm{c}}$ is proportional to the baseline level. The percentage of patients receiving the nateglinide/metformin combination and achieving $\mathrm{HbA}_{1 \mathrm{c}} \leq 7 \%$ has ranged from $35 \%$ to $70 \%$. In studies of initial combination therapy, nateglinide/ metformin has been found to be as effective, or more effective, than sulfonylureas (glyburide or glicazide) combined with metformin. However, in one open-label study of add-on to (recently initiated) metformin therapy, repaglinide was found to be more effective than nateglinide. In all reports, the nateglinide/metformin combination was found to be safe and well tolerated, and to have a very low hypoglycemic potential. In all studies where nateglinide/metformin was compared to metformin combined with any insulinotropic agent, hypoglycemia was less frequent and changes in body weight were smaller with the nateglinide/metformin combination.

\section{Disclosures}

Dr Israel is an employee of Novartis Pharmaceuticals Corporation (East Hanover, New Jersey) and holds company stock. Dr Baron is an employee of Sanofi-Aventis (Bridgewater, New Jersey) but was an employee of Novartis Pharmaceuticals Corporation at the time the manuscript was written and submitted for publication. Dr Istvan is an employee of Novartis AG (Basel, Switzerland) and holds company stock. Novartis AG markets nateglinide under the trade name Starlix ${ }^{\circledR}$.

\section{References}

Bailey CJ, Turner RC. 1996. Metformin. N Engl J Med, 334:574-9.

Baron MA. 2003. Comparison of repaglinide and nateglinide in combination with metformin: response to Raskin et al. Diabetes Care, 26:3361-2.

Centers for Disease Control and Prevention. National diabetes fact sheet: United States, 2005 [online]. Accessed September 11, 2007.URL: http://apps.nccd.cdc.gov/ddtstrs/template/ndfs_2005.pdf.

Ceriello A. 2000. The post-prandial state and cardiovascular disease: relevance to diabetes mellitus. Diabetes Metab Res Rev, 16:125-32.
Cook MN, Girman CJ, Stein PP, et al. 2007. Initial monotherapy with either metformin or sulphonylureas often fails to achieve or maintain current glycaemic goals in patients with type 2 diabetes in UK primary care. Diabet Med, 24:350-8.

DeFronzo RA. 1999. Pharmacologic therapy for type 2 diabetes mellitus. Ann Intern Med, 131:281-303.

DeFronzo RA, Ferrannini E, Simonson DC. 1989. Fasting hyperglycemia in non-insulin-dependent diabetes mellitus: contributions of excessive hepatic glucose production and impaired tissue glucose uptake. Metabolism, 38:387-95.

DeFronzo RA, Goodman AM, Multicenter Metformin Study Group. 1995. Efficacy of metformin in patients with non-insulin-dependent diabetes mellitus. N Engl J Med, 333:541-9.

Derosa G, D'Angelo A, Fogari E, et al. 2007. Effects of nateglinide and glibenclamide on prothrombotic factors in naive type 2 diabetic patients treated with metformin: a 1-year, double-blind, randomized clinical trial. Intern Med, 46:1837-46.

French JA. 2001. The role of new antiepileptic drugs. Am J Manag Care, 7:S209-S214.

Gerich J, Raskin P, Jean-Louis L, et al. 2005. PRESERVE- $\beta$ : two-year efficacy and safety of initial combination therapy with nateglinide or glyburide plus metformin. Diabetes Care, 28:2093-9.

Horton ES, Clinkingbeard C, Gatlin M, et al. 2000. Nateglinide alone and in combination with metformin improves glycemic control by reducing mealtime glucose levels in type 2 diabetes. Diabetes Care, 23:1660-5.

Horton ES, Foley JE, Shen SG, et al. 2004. Efficacy and tolerability of initial combination therapy with nateglinide and metformin in treatment-naive patients with type 2 diabetes. Curr Med Res Opin, 20:883-9.

Kahn SE. 2003. The relative contributions of insulin resistance and beta-cell dysfunction to the pathophysiology of Type 2 diabetes. Diabetologia, 46:3-19.

Mainous AG III, Baker R, Koopman RJ, et al. 2007. Impact of the population at risk of diabetes on projections of diabetes burden in the United States: an epidemic on the way. Diabetologia, 50:934-40.

Marre M, Van Gaal L, Usadel K-H, et al. 2002. Nateglinide improves glycaemic control when added to metformin monotherapy: results of a randomized trial with type 2 diabetes patients. Diabetes Obes Metab, 4:177-86.

McLeod JF. 2004. Clinical pharmacokinetics of nateglinide: a rapidlyabsorbed, short-acting insulinotropic agent. Clin Pharmacokinet, 43:97-120.

Narayan KM, Boyle JP, Thompson TJ, et al. 2007. Effect of BMI on lifetime risk for diabetes in the US Diabetes Care, 30:1562-6.

Natali A, Ferrannini E. 2006. Effects of metformin and thiazolidinediones on suppression of hepatic glucose production and stimulation of glucose uptake in type 2 diabetes: a systematic review. Diabetologia, 49:434-41.

Nathan DM, Buse JB, Davidson MB, et al. 2006. Management of hyperglycaemia in type 2 diabetes: a consensus algorithm for the initiation and adjustment of therapy. A consensus statement from the American Diabetes Association and the European Association for the Study of Diabetes. Diabetologia, 49:1711-21.

Pratley RE, Foley JE, Dunning BE. 2001. Rapid acting insulinotropic agents: restoration of early insulin secretion as a physiologic approach to improve glucose control. Curr Pharm Des, 7:1375-97.

Qiao Q, Pyorala K, Pyorala M, et al. 2002. Two-hour glucose is a better risk predictor for incident coronary heart disease and cardiovascular mortality than fasting glucose. Eur Heart J, 23:1267-75.

Raskin P, Klaff L, McGill J, et al. 2003. Efficacy and safety of combination therapy: repaglinide plus metformin versus nateglinide plus metformin. Diabetes Care, 26:2063-8.

Ristic S, Collober-Maugeais C, Cressier F, et al. 2007. Nateglinide or gliclazide in combination with metformin for treatment of patients with type 2 diabetes mellitus inadequately controlled on maximum doses of metformin alone: 1-year trial results. Diabetes Obes Metab, 9:506-11. 
Ristic S, Collober-Maugeais C, Pecher E, et al. 2006. Comparison of nateglinide and gliclazide in combination with metformin, for treatment of patients with type 2 diabetes mellitus inadequately controlled on maximum doses of metformin alone. Diabet Med, 23:757-62.

Rosenstock J, Hassman DR, Madder RD, et al. 2004. Repaglinide versus nateglinide monotherapy: a randomized, multicenter study. Diabetes Care, 27:1265-70.

Schatz H, Schoppel K, Lehwalder D, et al. 2003. Efficacy, tolerability and safety of nateglinide in combination with metformin. Results from a study under general practice conditions. Exp Clin Endocrinol Diabetes, 111:262-6.

Schwarz SL, Gerich JE, Marcellari A, et al. 2008. Nateglinide, alone or in combination with metformin, is effective and well tolerated in treatment-naive elderly patients with type 2 diabetes. Diabetes Obes Metab, 10:652-60.
Weaver JU, Robertson D, Atkin SL. 2004. Nateglinide alone or with metformin safely improves glycaemia to target in patients up to an age of 84. Diabetes Obes Metab, 6:344-52.

Weyer C, Bogardus C, Mott DM, et al. 1999. The natural history of insulin secretory dysfunction and insulin resistance in the pathogenesis of type 2 diabetes mellitus. $J$ Clin Invest, 104:787-94.

Wild S, Roglic G, Green A, et al. 2004. Global prevalence of diabetes: estimates for the year 2000 and projections for 2030. Diabetes Care, 27:1047-53. 